\title{
5. Life course sociology: Key concepts and applications in family sociology
}

\author{
Dirk Konietzka and Michaela Kreyenfeld
}

\section{INTRODUCTION}

Over the last decades, the life course has become an established framework for studying the dynamics of human behaviour in sociology and adjacent fields of social science. Fuelled by innovative methods and the growing availability of large-scale longitudinal data, research has moved away from cross-sectional and 'timeless' investigations, which still characterised sociological research of the 1980s (Elder et al. 2003; Mayer 2009). The concepts and methods of life course research have motivated a wide array of empirical projects in various fields of research, such as social stratification and mobility, education, labour market, regional mobility, migration, and family research. As a result, the life course perspective has become mainstream in sociological research. According to Mayer (2009, p. 414), it has become 'routine' and entered a 'stage of maturity'; whereas Kohli (2007, p. 253) has characterised it as 'indispensable' and a 'broadly accepted and practiced perspective' for understanding societal change and the structure of societies. Elder et al. (2003, p. 3) even claimed that it has developed into the 'pre-eminent theoretical orientation in the study of lives'. The adoption of the life course paradigm has significantly reframed how we view family behaviours and structures, and the degree to which these behaviours and structures have remained stable or changed (Elder 1977). It is because of the life course perspective that we now conceptualise family behaviours as dynamic processes that are shaped by institutional contexts.

Life course researchers share an interest in understanding behaviour that is located in time; i.e., 'between birth and death' (Mayer 2009, p. 414) and 'from childhood to old age' (Elder et al. 2003, p. 4). There is a common terminology in this research: states, transitions, trajectories, and life domains are key terms that structure our thinking along the life course. Furthermore, the use of longitudinal data (qualitative or quantitative) is an essential ingredient of the life course paradigm. Despite these commonalities, different research streams exist. Some scholars seek to further develop the life course into a 'genuinely interdisciplinary endeavour' (Bernardi et al. 2019; Levy et al. 2005; Settersten 2003). Others advocate for understanding the life course as an inherently sociological concept that focuses on the interplay of life course behaviour and societal institutions; and, thus, on how historical and socio-political contexts shape life course patterns (Diewald and Mayer 2009; Mayer 2009; Wingens 2020).

In this chapter, we provide an introduction to key concepts and terminology of life course sociology, and explain how the life course perspective is employed in the area of family research. This overview focuses on research that particularly addresses the link between the life course and the social structure; i.e., we will focus on how societal macro-level phenomena and long-term changes in social integration relate to family dynamics. We also draw heavily on quantitative life course research (for an overview on qualitative research, see Bernardi in this volume). We start with a discussion of the evolution of the life course approach in soci- 
ology (Section 2). We then introduce the reader to basic terminology, data, and methods that have 'co-evolved' with the advancement of the concept (Section 3). In the following section, we address the contribution of life course research to our understanding of societal change (Section 4). In the final section, we conclude with a discussion of the avenues and challenges for the life course paradigm in family sociology.

\section{LIFE COURSE ANALYSIS AND SOCIAL STRUCTURE}

\subsection{Early Research on the Life Course}

The notion that the life course is not a random flow of events, but is instead characterised by a clear order of social roles that people enact over their lifetimes, has existed in European cultures for centuries. Since the sixteenth century, the concepts of 'life stairs' or 'steps of ages' have been used to describe how people progress from birth to old age. Paintings, tapestries, and embroidery have depicted life as a staircase that moves upwards from birth to middle age, and downwards in later life as a person's health and vigour deteriorate. These life stairs commonly reflected a gendered life course, emphasising the distinct roles women and men inhabit across their lives. These depictions are early evidence that there was a clear perception that people's lives are structured by age (Ehmer 1996). For age to be assigned such a significant social meaning, a number of preconditions had to be met. First, people had to acquire an understanding of temporal order and time, a dimension that Elias (1982 [1939]; 1988 [1939]) illustrated in his seminal work on the 'civilizing process'. Second, people also had to have knowledge of their 'own age' before they could develop an image of an age structuring of the life course. Ariès (1962 [1960], p. 16) argued that the 'personal importance of the idea of age' was accompanied by the official documentation of it. Thus, age structuring must be seen in the context of the registration of marriage, childbirth, and death by parishes; and, later, by state authorities (see also Section 4 on the 'chronologically standardised modern life course').

In order to understand the social meaning of age and age structuring, early sociological studies turned to the ethnographical study of rituals ('rite de passage'), such as engagements, marriages, and burials (Bossard and Boll 1948; Linton 1942). Linton (1942, p. 592) illustrated the significance of status passages by making a fine distinction between the biological process of death and the social rites of a funeral. Thus, it is not necessarily the death, but the 'funeral rites' that mark the separation of an individual from a society. Likewise, it is not the birth of a child that marks his/her entry into a community, but the child's baptism or participation in a similar ceremony or practice that signals the acceptance of a new-born as a member of society. Initiation ceremonies, such as communion, confirmation, and bat/ bar mitzvah, mark an individual's entry into adult status in different cultures and societies. These status passages are social constructs that obtain a meaning only because society attaches privileges and obligations to certain life phases. It therefore appears that life phases and the obligations, duties, and meanings associated with them are not fixed, but are subject to a process of social construction. While this process applies to all life phases, it is probably most pronounced for childhood. As Ariès (1962 [1960]) pointed out, a perception of childhood was absent in medieval times. It was only later that childhood emerged as a separate phase, distinct from adulthood. 
The idea of an age-structured life course is also present in early family research. Glick employed the term family life cycle to illustrate the different phases of family life:

Typically, a family comes into being when a couple is married. The family gains in size with the birth of each child. As the children leave home for employment or marriage, the size of the family shrinks gradually back to the original two persons. Eventually one and then the other parents die and the family life cycle has come to an end. (1947, p. 164)

Studies of this kind built an important foundation for contemporary research on life course behaviour (Glick 1947; Lansing and Kish 1957). However, the strong normative underpinning of these early studies of family behaviour is rather striking. The recognition that families are not constituted by marriage alone was not present in this definition, even though single parenthood and stepfamilies have existed throughout history. Furthermore, the citation highlights that the author had a clear perception of the temporal order of family events. However, the different phases of the family life cycle appear to be rather static categories that seem strangely detached from the individual life course experience and 'the processes that might govern development in the life course as a whole' (Mortimer 2008, p. 217).

\subsection{Children of the Great Depression}

Glen Elder's pioneering research in Children of the Great Depression (Elder 1974) is a major foundational work of life course sociology. Based on two longitudinal child development studies (the Oakland Growth Study of children born in 1920-21 and the Berkeley Guidance Study of children born in 1928-29), Elder found that the hardships of the Great Depression did not have universal effects on children's later outcomes. Instead, the analysis showed that how these children fared in later life depended on how old they were during the Great Depression. In many respects, Elder's work was a rejection of the static 'age structure models' (see above). It provided a novel and ground-breaking perspective for at least three reasons.

First, it used data that captured not just a short time span, but more than 30 years (and, eventually, 50 years) of observation, from childhood to middle age. This long time span established the groundwork for studies on the consequences of early life events for later outcomes. Thus, Elder went beyond static age structure models by framing the life course as a dynamic entity in which earlier phases interact with later ones. He elucidated that 'timing' and 'time' mattered; i.e., that while the age at which a person is subject to certain experiences and social contexts may have an immediate impact, the effects can also unfold over time. Hence, he argued, life has a 'memory', and positive and negative events and experiences may pile up over time, leading to cumulate advantages or disadvantages in later life (Elder et al. 2007). Elder further posited that some events may be more consequential than others, and they may mark turning points in people's lives (Elder et al. 2003, p. 8). Thus, he observed, there are path dependencies, because certain events and decisions can result in conditions that do not allow people to change tracks easily. Elder also emphasised that life courses never develop in isolation. The concept of linked lives highlights the reality that life courses are interlocked with the experiences of other people. This is most evident in family behaviour, as events and statuses of family members - such as a partner having a chronic illness or a child deciding to leave the parental home - have an immediate bearing on the life courses of the other family members. The concept also encompasses the idea that life courses are closely intertwined. For example, within a couple context, individual work and fertility trajectories are mutually related 
and interact with each other. Thus, this perspective calls for a dyadic view of behaviour. The linked lives perspective also encompasses the idea that life courses are located in the generational hierarchy, a concept that has inspired a large body of work on the intergenerational transmission of family behaviour, such as the transmission of fertility timing (e.g., Morosow and Trappe 2018), cohabitation (e.g., Liefbroer and Elzinga 2012), and divorce and separation (e.g., Engelhardt et al. 2002).

Second, Elder's work motivated a novel type of data collection for sociological research. While psychological studies had drawn on longitudinal data before, these studies often captured a few years only, and focused narrowly on particular themes, such as child development. Elder brought the idea of longitudinal data collection into sociological research. 'Longitudinal' means more than just going beyond cross-sectional work; it involves a holistic approach that aims to cover the entire life course. In this spirit, projects of retrospective and prospective data collection have been initiated. These include large-scale longitudinal quantitative projects, as well as qualitative studies that seek to provide a better understanding of how motivations, feelings, and behaviour are located in time and in the biographical context (see Bernardi in this volume). Classic examples of quantitative life course projects are the British and German cohort studies (Brückner and Mayer 1998; Elliott and Shepherd 2006). Moreover, recent family surveys such as the Generations and Gender Programme and the German family panel touch on Elder's agenda (Gauthier et al. 2018; Huinink et al. 2011).

Third, and equally important, Elder systematically linked life courses and their social and political contexts (Elder et al. 2003). By defining life courses as 'social pathways of human lives' that are embedded in 'historical time and place', he shed light on the interrelation of cohort-specific life courses and changing social structures. This theoretical perspective was further developed by proponents such as Karl Ulrich Mayer, who emphasised the pivotal role of the welfare state in shaping life course patterns (for a more detailed discussion, see Section 4).

\subsection{Basic Concepts}

At the heart of the life course approach is the concept of time; and, thus, of the duration, spacing, sequencing, and order of events in the lifetimes of individuals (Elder 1975, 1985). In everyday language, the term 'life course' is often used interchangeably with life span. However, life span is a concept adopted in psychology for research that examines the psychological development of an individual (Baltes and Schaie 1973). Originally, life span psychology and life course sociology at least partly evolved together. Elder's pioneering work, Children of the Great Depression, was based on data collected for psychological studies on child development. Despite their shared terminology and shared origins, the life course approach is now seen as a distinct sociological concept that diverges markedly from life span psychology (Diewald and Mayer 2009). Hence, the choice of terminology is indicative of the disciplinary standpoint. This is also the case for the life cycle approach, which featured as a core sociology concept in the work of Glick (1947). Today, life cycle approaches are used primarily in research on intertemporal decision-making in economics (Ando and Modigliani 1963). Apart from their shared commitment to the notion that 'time matters', there are few commonalities between life course sociology and economic life cycle studies.

Events, states, and transitions are key concepts of life course research. An event is 'a qualitative change that can be situated in time' (Allison 2014, p. 2). It is important that an event marks a 'sharp disjunction' from what proceeds and what follows (Allison 2014). Classical 
examples of a qualitative change are the transition from the state of being single to the state of being married, and the transition from being childless to having a child. In addition to representing a sharp disjunction, it must be possible to place the event in time. It is also common to distinguish between absorbing and recurrent events. An absorbing event is experienced only once per lifetime. An obvious example is death. A recurring event is an event that can be experienced several times in a lifetime, such as childbirth or marriage. Even though childbirth and marriage are, by nature, recurring events, they can be turned into absorbing events by focusing on the transition of a certain order (e.g., first birth or first marriage). Transitions are embedded in trajectories, which are pathways 'defined by the aging process or by movement across the age structure' (Elder 1985, p. 31). In sociological life course research, it is also relevant to distinguish between life domains or social spheres. 'Domains or life areas such as education, working life, intimate relationships and housing clearly are interconnected, but analytically it is extremely useful to consider them as separate areas for measurement and data organization purposes' (Giele and Elder 1998, p. 93).

Life course sociology contributes to research on social stratification and social inequality by addressing the 'temporal embeddedness' of individual lives in social structures. Hence, the sociological study of the life course aims to map, describe, and explain the 'synchronic and diachronic distribution of individual persons into social positions across the lifetime' (Mayer 2004, p. 163). Some transitions in the life course are 'age-standardised' through legal regulations. For example, legal norms define the minimum age at marriage. Apart from legal prescriptions, the life course is governed by age and sequencing norms that define appropriate behaviour. These norms prescribe the right time to move out of the parental home, to have a child, and to get married. They also define the right order of events; i.e., whether it is socially acceptable to have a child before marriage, or to marry before being established in the labour market. Age and sequencing norms vary across time, societies, and population subgroups (Settersten and Hägestad 1996). This is also evident in the case of old age. As a result of increasing longevity and 'healthy ageing', the social and cultural representations of ageing have shifted significantly across time (Staudinger 2015). Age norms are usually surveyed by asking respondents to report the 'best', 'proper', 'appropriate', 'optimal', or 'maximum' age for experiencing a certain event (Marini 1984; Settersten and Mayer 1997; Settersten 2003, p. 88). Empirical research has examined to what extent age and sequencing norms have a grip on family behaviour (Billari and Liefbroer 2007).

\section{LIFE COURSE DATA AND METHODS}

\subsection{Event History Modelling}

A guiding principle of the life course perspective is that human behaviour is located in time, and that its analysis requires a dynamic approach. Thus, it comes as no surprise that the 'life course' has closely evolved with the emergence of event history techniques in sociology (Elder 1985; Mayer and Tuma 1990). Event history analysis denotes 'a class of statistical methods for studying the occurrence and timing of events' (Allison 2014, p. 1). Most of the event history models in family sociology are single-destination state models, i.e., they focus on single outcomes (such as first, second, or third childbirth; first time leaving home; first divorce). However, it may also be appropriate to focus on more than one outcome. For example, an 
individual may leave home in order to live alone or to cohabit. Similarly, an individual may exit the family status 'married' by moving into the state of being 'divorced' or 'widowed'. Competing risk models are event history models for more than one outcome.

Another key feature of event history analysis is that it allows us to study the timing and the spacing of life course events, and how they relate to key variables of interest. It also provides researchers with the tools they need to study how the timing and the spacing of an event is influenced by time-constant and time-varying covariates. Time-varying covariates change their value as a process unfolds. The differentiation between time-constant and time-varying covariates has been vital to progress in family research. For example, the modelling of education as a time-varying trait illustrated that it is not having a higher education per se that induces women to postpone childbirth, but rather their participation in the educational system (Blossfeld and Huinink 1991). After they have completed their education, highly educated women often progress more rapidly to having a first child than their less educated counterparts. Likewise, highly educated women may more rapidly progress to a second or third child after they have 'initiated' their childbearing biography (Bartus et al. 2013; Kreyenfeld 2002). Numerous dimensions of family behaviour have been explored in this way, such as the relationship between employment and childbearing (Matysiak and Vignoli 2008), the effect of pre-birth cohabitation on union stability (Liefbroer and Dourleijn 2006), the effect of age norms for leaving home (Billari and Liefbroer 2007), the role of networks in family behaviour (Lois and Arránz Becker 2014), and the determinants of the return to the labour market after childbirth (Aisenbrey et al. 2009), to name only a few examples.

Event history modelling greatly advanced family research and established a dynamic perspective on family behaviour. However, like most other statistical techniques, it relies on assumptions that may lead to oversimplification. Event history models are, ultimately, regression models in which the outcome variable is a rate. The drawback of determining a rate is that it conflates 'timing' and 'quantum'; i.e., the lifetime probability of an individual experiencing an event. While this issue is irrelevant for the study of death, as the whole population will eventually experience the event of interest, it is crucial for family behaviour. There is a substantive difference between the timing of first parenthood (age at first birth) and the factors that will eventually lead to lifelong childlessness (probability of ever having children). Although model extensions ('split population models') have been proposed to address this shortcoming, these extensions have never diffused into mainstream empirical research. In addition, event history modelling is a 'piecemeal approach', as only single transitions are examined: i.e., after the event of interest occurs, the process ends, and the subsequent life course is disregarded. Thus, event history modelling is only a partial response to the initial claim to adopt a holistic perspective on the life course (Elder 1985, p. 31).

\subsection{Sequence Analysis}

Inspired by the works of Kohli $(1985,1986)$ and Beck (1992 [1986]), sociologists developed a lively interest in the question of whether life courses were becoming more fragile and 'individualised'; e.g., whether (male) workers' 'normal biographies' eroded, and how divorce and separation translated into life course disorder in the family domain (Heinz 2003; Settersten 2003, see also Section 4). However, proponents of the approach expressed a certain scepticism that the available methods, such as event history modelling, would be able to adequately map complex processes such as the de-standardisation of life courses. Meeting such a challenge 
would require taking the 'trajectory dimension' seriously (Mayer 1990, p. 13). For a long time, unresolved conceptual and methodological problems caused the analysis of trajectories and sequences - all the more the 'whole life course' - to be seen as an unrealistic endeavour (Mayer 1990; Settersten and Mayer 1997).

It was the advancement of sequence analysis and the diffusion of this method into the social sciences that revitalised the original idea of developing a holistic perspective on the life course. Sequence analysis is a technique that originated from studies that had examined the order of the building blocks of DNA (Abbott 1995; Abbott and Forrest 1986). Like DNA sequences, the states that characterise a life course could be modelled as an ordered object. For example, an individual's trajectory of intimate relationships may be represented as a succession of the states 'single', 'cohabiting', 'married', 'divorced', and 'remarried'. Sequence analysis compares the sequences of different individuals, and creates clusters of individuals with similar life course patterns. Furthermore, sequence analysis is now implemented in software packages that have the power to visualise individual life courses. 'Sequence index plots' are appealing techniques for displaying the complexity of the entire life courses of individuals. Sequence analysis has been heavily employed to map and study family diversity, and how it compares across birth cohorts and countries (Aisenbrey and Fasang 2017; Elzinga and Liefbroer 2007; Fasang 2014; Jalovaara and Fasang 2015; Van Winkle 2018; Zimmermann and Konietzka 2018).

While sequence analysis enabled researchers to realise the original ideal of developing a holistic view of the life course, its use also has drawbacks. While event history modelling can deal with censored data of any kind, sequence analysis requires observations of the same or similar length. As a consequence, the data requirements for conducting sequence analysis can be substantial. For example, as panel surveys suffer from attrition, researchers rarely have access to data in which all individuals contributed equally long sequences. Beyond these more technical issues, sequence analysis has so far remained largely an explorative method. Many of the decisions that are made in the process of data analysis are subject to the discretion of the researcher. For example, the researcher can select the states or choose the algorithm that generates clusters. Thus, the results rely on the many decisions that the researcher has to make along the way that could have a substantial impact on the overall results. Despite these shortcomings, sequence analysis has clearly breathed new life into the life course approach, and has advanced the study of family behaviour and family diversity.

\section{THE LIFE COURSE AND SOCIAL CHANGE}

\subsection{Cohorts and Social Change}

A key interest of life course sociology is investigating the 'bond', 'interplay', or 'intersection' of personal life and societal change (Elder 1985; Elder et al. 2003; Riley 1987). To elucidate such relationships, researchers had to develop an understanding of the conceptual differences between age, cohort, and period. Many prior sociological studies were prone to conflating cohort and age effects. Cross-sectional data would, for example, reveal that attitudes became more conservative as people got older. However, these data turned out to be only a 'slice' through the life courses in the 'stream of history' (Ryder 1965, p. 844). Whether an effect was indeed a true 'age effect', or was instead due to 'cohort effects' - i.e., to older generations 
adopting more conservative attitudes - was a question that could only be answered by applying an analytical framework that set age at the centre of sociological inquiry (Riley 1987).

The differentiation between cohort and age effects also drew attention to the cohort replacement as a motor for societal change. On the one hand, society provided continuity by socialising new cohort members into roles and positions. On the other hand, the demographic processes of birth and death meant that the society was subject to the constant replacement of its members. While the older generation left their imprints on the new generation, because this imprint was never perfect, the 'demographic metabolism' (Ryder 1965, p. 843) opened up the potential for societal change.

Birth in a given historical time and place was also seen as having the potential to unify members of a particular birth cohort, because they were assumed to share 'formative' experiences (Ryder 1965, p. 854). Although there were controversies about the terminology, ${ }^{1}$ the idea that individual birth cohorts have a unique character was posited by Karl Mannheim as early as the 1920s:

Generation location is based on the existence of biological rhythm in human existence - the factors of life and death, a limited span of life, and aging. Individuals who belong to the same generation, who share the same year of birth, are endowed, to that extent, with a common location in their historical dimension of the social process. (Mannheim 1952, p. 163)

According to Mannheim, members of adjacent birth cohorts may develop a unique culture and identity that is shaped by the conditions at birth and childhood. Sociological studies followed the notion that a 'generation' unified people with a 'distinctive culture and/or a self-conscious identity by virtue of having experienced the same historical events at roughly the same time in their lives' (Alwin and McCammon 2003, p. 27). Theoretical models such as the theories of 'value change' and the 'second demographic transition' (Inglehart 1971; Lesthaeghe 1995) have further developed the idea that cohort-specific values shape societal change. In the same vein, it has become standard practice to describe changes in family dynamics along birth cohorts (e.g., Berrington et al. 2015; Billari and Liefbroer 2010).

In Elder's landmark study, the Great Depression represented a severe period effect. Elder showed that the effects that the Great Depression had on children depended on their ages during the economic upheavals. He later examined the repercussions of World War II for family behaviour. In particular, he highlighted that the timing of entry into military service during World War II seriously weakened family stability (Pavalko and Elder 1990). Many subsequent studies capitalised on the idea that period effects may have differential effects on life course patterns. A very influential study in this context is Richard Easterlin's examination of the significance of cohort size for later life outcomes. Easterlin (1987) argued that the members of the exceptionally large cohorts born during the post-war baby boom were subject to fierce competition on the labour market, which, in turn affected their family behaviour; i.e., it resulted in late parenthood and a small family size. Examples of recent studies that looked at how period effects influence life course outcomes are investigations of the impact on family behaviour of the fall of the Berlin Wall or the global financial crisis (Diewald et al. 2006; Jónsson 2018; Kreyenfeld 2003). 


\subsection{The Welfare State and the Institutionalisation of the Modern Life Course}

A seminal application of the life course approach to societal change is Martin Kohli's model of the 'institutionalization of the life course' (Kohli 1985, 1986; Kohli and Meyer 1986). The model provides an ideal-type framework for describing the modern life course, including its patterns, structures, and changes, by contrasting the life patterns of Western societies of the late eighteenth and early nineteenth centuries with those of the 'fully modernised societies of the second half of the 20th century' (Kohli 2007, p. 254). In pre-modern societies, lives were subject to unpredictable risks, such as death due to epidemics, wars, and hunger. Life was predetermined by traditional and 'local' institutions and, thus, by the obligations and normative constraints imposed by the family and the community. The process of modernisation, which was unleashed by industrialisation, urbanisation, and the demographic transition, had a fundamental impact on people's lives: as life expectancy rose, lifetimes became more predictable. Increasing social and geographical mobility set individuals 'free from the bonds of status, locality and family of origin'. However, the process of modernisation also led to the emergence of new modes of social control and integration that now 'focused on individuals as the basic units of social life' (Kohli 2007, p. 255). Within the new regime, people were 'processed' through the social structure, primarily based on the criteria of 'chronological age' (Kohli 2007, p. 255). By implementing compulsory schooling and a statuary pension age, the state created the stages of the 'modern life course'. Thus, completion of school and entry into retirement marked the main status passages that created the tri-partitioning of life into education - gainful employment - retirement.

The concept of an ordered and standardised life course was clearly developed against the backdrop of the strongly gendered employment trajectories that prevailed in advanced economies in the post-war period. Women's biographies were defined primarily in reference to the family life course (Kohli 1985, pp. 6-8). While the life course concept was geared to the male life course, it nevertheless sharpened the awareness of the risks that women were exposed to. Thus, it became clear that as the welfare state was mainly focused on protecting the 'male breadwinner family' from economic risks, a woman's life course risks were not fully buffered by welfare state regulations, particularly if the woman was unmarried and could not rely on 'derived' rights (for more detail, see Bradshaw and Nieuwenhuis or Neyer in this volume). The model of the 'institutionalised life course' also raised the question of whether the post-war period was exceptional, and whether life course patterns have been gradually eroding since the 1970s (Beck 1992 [1986]; Kohli 1986, p. 294). A large body of longitudinal research was built on the assumptions that disorder was increasing and that working careers were becoming more individualised (e.g., Blossfeld 1986; Rindfuss et al. 1987). Scholars also examined how the 'tri-partitioned' modern life course has been eroding, as the previously sharp divides between work and retirement and work and education are increasingly blurred. Thus, the simultaneity of states has become an important concept in the study of life course patterns.

Numerous studies have also turned their attention to the growing diversity and pluralisation of the family life course (Billari 2001; Bras et al. 2010; Brückner and Mayer 2005; Konietzka 2010; Zimmermann 2020). These studies have generated important 'stylised facts' of family behaviour in post-modern societies, including that in large parts of the population, marriage and childbirth are being either postponed or forgone; and that as a result of these trends, life course transitions that had been intertwined in the mid-twentieth century have 'de-coupled'. This research showed that moving out of the parental home no longer coincides with marriage 
(Andersson and Philipov 2002), and that the 'normal' sequence of events of marriage and childbirth no longer holds for the younger cohorts. At the same time, a new phase in the early life course emerged: namely, that of co-residing without marriage. This trend led to studies being published on the timing and duration of cohabitation (e.g., Jalovaara and Kulu 2018). Likewise, divorce and separation were identified as key elements of the deviation from the allegedly 'normal' family life course. Research on repartnering, remarriage, and stepfamily behaviour, and on 'grey divorce', addressed the resulting family transitions in the middle and later life course (e.g., Brown et al. 2019; Henz and Thomson 2005; Ivanova et al. 2013). Despite these fundamental changes in post-modern life courses, life course patterns are still gendered: compared with men's life courses, women's life courses are more likely to be characterised by 'non-standard' employment sequences, part-time work, and career interruptions (see Grunow in this volume).

More generally, the life course approach provides a 'toolkit' for understanding how the modern welfare state structures individual life chances. The state supports and enables life course transitions via social policy regulations, but it also restricts life course options (Mayer and Schoepflin 1989). The welfare state enacts its power in manifold ways: e.g., by setting legal ages for school entrance, marriage, and retirement; or by introducing compulsory military service. Furthermore, state policies often favour certain types of behaviour more than others. For example, marriage grants support particular life course transitions (namely, marriage), while discriminating against others. By focusing on the welfare state, the life course approach has been used to build a bridge to comparative welfare state research; i.e., to examine social policies and their implications for social inequalities from a cross-national perspective (Daly 2020). Several more recent studies have emerged from this logic that have explored processes of social stratification and family dynamics by comparing patterns across countries (Jalovaara and Fasang 2015; Van Winkle 2018; Zimmermann and Konietzka 2018).

\section{CONCLUSION}

Our aim in this chapter was to provide an introduction to the basic concepts and terminology of life course sociology. We also sought to elucidate how this approach has been employed in quantitative family sociology. The key contribution of life course research to family sociology has been to cast a dynamic perspective on family behaviour. Its most significant achievement is, perhaps, that today it comes naturally to study birth, marriage, leaving home, or divorce as dynamic events in the life course of individuals. Event history modelling has become widely accepted as an appropriate tool for examining the determinants of family behaviour, including how education, employment, unemployment, occupation, household context, family of origin, and family and friendship networks influence transitions in the family domain. In addition, advancements in sequence analysis have enabled researchers to develop a holistic view; e.g., to study heterogeneity, pluralisation, and de-standardisation of family behaviour across the life course. Important data collection projects have been initiated in the spirit of the life course paradigm. The most important of these projects in the European context are the Generations and Gender Survey and the many national surveys that have a strong connection to this, such as the German family panel (pairfam), the 'Netherlands Kinship Panel Survey', and the new panel survey 'Family Research and Demographic Analysis'. Data of this kind make it possible to locate behaviour within both biographical and historical contexts. The availability of these 
data calls for the development of a dyadic approach that enables researchers to study how individual life courses are intertwined with each other within intimate relationships and families. Moreover, as these datasets enlarge our understanding of family behaviour in individual European countries and from a cross-national perspective, analyses based on these data can help us better understand how social policy contexts influence life course patterns.

What are the prospects for life course sociology enhancing our understanding of contemporary family patterns in the twenty-first century? As we already alluded to in the introduction, there is controversy about the future avenues of life course research. Some scholars have argued that the life course should be developed further into an interdisciplinary framework (Bernardi et al. 2019; Levy et al. 2005; Settersten 2003). Others have claimed that it would be more beneficial to view the life course as a sociological concept that should be geared to the intersection of the social-political context and processes of social stratification (Diewald and Mayer 2009; Mayer 2009; Wingens 2020). From the latter point of view, the key challenge of life course sociology is to enhance our understanding of 'the impact of particular state interventions and their consequences on life course decisions' (Mayer and Schoeflin 1989, p. 203). With its variations in policy contexts, Europe provides an ideal laboratory for such an endeavour (Aisenbrey and Fasang 2017; Jalovaara and Fasang 2015; Neyer and Andersson 2008; Van Winkle 2018; Zimmermann and Konietzka 2018). On the one hand, this type of research has advanced our knowledge of how welfare policy contexts shape family behaviour. On the other hand, the more causal investigations of single policy interventions have been left to economists, who have largely disregarded the life course approach. It should be one of the ambitions of the life course agenda to regain territory in this realm, and to contribute more extensively to research on policy interventions, policy measures, and policy configurations in family behaviour. Another challenge is to adequately map family behaviour in the twenty-first century from a 'linked lives' perspective, particularly for couples who have to synchronise their care and employment activities, but also for post-separation families whose individual life course transitions may hinge on the behaviour of their ex-partners. Methodologically, multi-channel modelling has provided a new tool for mapping the interdependences of several trajectories (e.g., Gauthier et al. 2010). Finally, the question of how family events mark turning points in the life courses of individuals remains a highly relevant issue. The re-traditionalisation of family behaviour after first birth could have profound biographical and societal implications (see Grunow in this volume). While it is obvious that traditional care patterns can have long-term implications for women's subsequent career advancement, more recent research suggests that traditional care patterns also have adverse implications for the life courses of fathers. For example, it has been shown that a father's post-separation behaviour and his long-term relationship with his children are contingent on his behaviour prior to separation (e.g., Poortman 2018). Studies of this kind not only uphold the original idea of developing holistic life course perspectives; they also emphasise how important it is to view behaviour within a biographical context.

\section{NOTE}

1. Ryder (1965, p. 853) insisted that 'cohort' was the correct terminology, and that 'generation' should only be used for intergenerational relationships. 


\section{REFERENCES}

Abbott, A. (1995), 'Sequence analysis: New methods for old ideas', Annual Review of Sociology, 21, 93-113.

Abbott, A. and J. Forrest (1986), 'Optimal matching methods for historical sequences', Journal of Interdisciplinary History, 16 (3), 471-94. doi:10.2307/204500.

Aisenbrey, S. and A. Fasang (2017), 'The interplay of work and family trajectories over the life course: Germany and the United States in comparison', American Journal of Sociology, 122 (5), 1448-84. doi:10.1086/691128.

Aisenbrey, S., M. Evertsson, M., and D. Grunow (2009), 'Is there a career penalty for mothers' time out? A comparison of Germany, Sweden and the United States', Social Forces, 88 (2), 573-605. doi:10 $.1353 /$ sof.0.0252.

Allison, P.D. (2014), Event History and Survival Analysis, Beverly Hills, CA: Sage.

Alwin, D.F. and R.J. McCammon (2003), 'Generations, cohorts, and social change', in J.T. Mortimer and M.J. Shanahan (eds), Handbook of the Life Course, New York: Kluwer Academic, Plenum Publishers, pp. 23-49.

Andersson, G. and D. Philipov (2002), 'Life-table representations of family dynamics in Sweden, Hungary, and 14 other FFS countries: A project of descriptions of demographic behavior', Demographic Research, 7, 67-144. doi:10.4054/DemRes.2002.7.4.

Ando, A. and F. Modigliani (1963), 'The "life-cycle" hypothesis of saving: Aggregate implications and tests', American Economic Review, 53 (1), 55-84. www.jstor.org/stable/1817129.

Ariès, P. ([1960] 1962), Centuries of Childhood: A Social History of Family Life, London: Jonathan Cap.

Baltes, P.B. and K.W. Schaie (eds) (1973), Life-Span Developmental Psychology: Personality and Socialization, Orland: Academic Press.

Bartus, T., L. Murinkó, I. Szalma, and B. Szél (2013), 'The effect of education on second births in Hungary: A test of the time-squeeze, self-selection, and partner-effect hypotheses', Demographic Research, 28, 2-32. www.jstor.org/stable/26349944.

Beck, U. (1992 [1986]), Risk Society, Towards a New Modernity, translated from the German, Thousand Oaks, CA: Sage.

Bernardi, L., J. Huinink, and R.A. Settersten (2019), 'The life course cube: A tool for studying lives', Advances in Life Course Research, 41, 1-13. doi:10.1016/j.alcr.2018.11.004.

Berrington, A., J. Stone, and E. Beaujouan (2015), 'Educational differences in timing and quantum of childbearing in Britain: A study of cohorts born 1940-1969', Demographic Research, 33, 733-64. www.jstor.org/stable/26332003.

Billari, F.A. (2001), 'The analysis of early life courses: Complex descriptions of the transition to adulthood', Journal of Population Research, 18 (2), 119-42. doi:10.1007/BF03031885.

Billari, F.A. and A. Liefbroer (2007), 'Should I stay or should I go? The impact of age norms on leaving home', Demography, 44 (1), 181-98. doi:10.1353/dem.2007.0000.

Billari, F.A. and A. Liefbroer (2010), 'Towards a new pattern of transition to adulthood?', Advances in Life Course Research, 15 (2-3), 59-75. doi:10.1016/j.alcr.2010.10.003.

Blossfeld, H.-P. (1986), 'Career opportunities in the Federal Republic of Germany: A dynamic approach to the study of life-course, cohort, and period effects', European Sociological Review, 2 (3), 208-25. doi:10.1093/oxfordjournals.esr.a036419.

Blossfeld, H.-P. and J. Huinink (1991), 'Human capital investments or norms of role transition? How women's schooling and career affect the process of family formation', American Journal of Sociology, 97 (1), 143-68. www.jstor.org/stable/2781641.

Bossard, J.H.S. and E. Boll (1948), 'Rite of passage: A contemporary study', Social Forces, 26 (3), 247-55. doi:doi:10.2307/2572047.

Bras, H., A. Liefbroer, and C.H. Elzinga (2010), 'Standardization of pathways to adulthood? An analysis of Dutch cohorts born between 1850 and 1900', Demography, 47 (4), 1013-34. doi:10.1007/ BF03213737.

Brown, S.L., I. Lin, and A.M. Hammersmith (2019), 'Repartnering following gray divorce: The roles of resources and constraints for women and men', Demography, 56, 503-23. doi:10.1007/ s13524-018-0752-x. 
Brückner, E. and K.U. Mayer (1998), 'Collecting life history data: Experiences from the German Life History study', in J.Z. Giele and G.H. Elder (eds), Methods of Life Course Research: Qualitative and Quantitative Approaches, Thousand Paks, CA: Sage, pp. 152-81.

Brückner, E. and K.U. Mayer (2005), 'The de-standardization of the life course: What it might mean and if it means anything whether it a actually took place?', Advances in Life Course Research, 9, 27-53. doi:10.1016/S1040-2608(04)09002-1.

Daly, M. (2020), 'Generations, age and life course: Towards an integral social policy framework of analysis', Contemporary Social Science, 49 (2), 291-301. doi:10.1080/21582041.2018.1455107.

Diewald, M. and K.U. Mayer (2009), 'The sociology of the life course and life span psychology: Integrated paradigm or complementing pathways?', Advances in Life Course Research, 14 (1), 5-14. doi:10.1016/j.alcr.2009.03.001.

Diewald, M., A. Goedicke, and K.U. Mayer (eds) (2006), After the Fall of the Wall: Life Courses in the Transformation of East Germany, Stanford, CA: Stanford University Press.

Easterlin, R.A. (1987), Birth and Fortune: The Impact of Numbers on Personal Welfare, Chicago, IL: University of Chicago Press.

Ehmer, J. (1996), 'The life stairs: Aging, generational relations, and small commodity production in Central Europe', in T.K. Hareven (ed.), Ageing and Generational Relations over the Life Course: A Historical and Cross-Cultural Perspective, Berlin: De Gruyter, pp. 53-74.

Elder, G.H. (1974), Children of the Great Depression, Chicago, IL: University of Chicago Press.

Elder, G.H. (1975), 'Age differentiation of the life course', Annual Review of Sociology, 1, 165-90. doi: 10.1146/annurev.so.01.080175.001121.

Elder, G.H. (1977), 'Family history and the life course', Journal of Family History, 2 (4), 279-304. doi: 10.1177/036319907700200402.

Elder, G.H. (1985), 'Perspectives on the life course', in G.H. Elder (ed.), Life Course Dynamics: Trajectories and Transitions 1968-1980, Ithaca, NY: Cornell University Press, pp. 23-49.

Elder, G.H., M.K. Johnson, and R. Crosnoe (2003), 'The emergence and development of life course theory', in J.T. Mortimer and M.J. Shanahan (eds), Handbook of the Life Course, New York: Springer, pp. 3-19.

Elder, G.H., A.E. Willson, and K.M. Shuey (2007), 'Cumulative advantage processes as mechanisms of inequality in life course health', American Journal of Sociology, 112 (6), 1886-924. doi:10.1086/ 512712 .

Elias, N. (1982 [1939]), The History of Manners (The Civilizing Process, Volume 1), New York: Pantheon.

Elias, N. (1988 [1939]), Über die Zeit, Wiesbaden: Campus.

Elliott, J. and P. Shepherd (2006), 'Cohort profile: 1970 British Birth Cohort (BCS70)', International Journal of Epidemiology, 35 (4), 836-43. doi:10.1093/ije/dyl174.

Elzinga, C.H. and A. Liefbroer (2007), 'De-standardization of family-life trajectories of young adults: A cross-national comparison using sequence analysis', European Journal of Population, 23 (3-4), $225-50$.

Engelhardt, H., H. Trappe, and J. Dronkers (2002), 'Differences in family policy and the intergenerational transmission of divorce: A comparison between the former East and West Germany', Demographic Research, 6, 295-324. www.jstor.org/stable/26348049.

Fasang, A. (2014), 'New perspectives on family formation: What can we learn from sequence analysis?', in P. Blanchard, F. Bühlmann, and J.-A. Gauthier (eds), Advances in Sequence Analysis: Methods, Theories and Applications, Berlin: Springer.

Gauthier, A.H., S. Laia, F. Cabaço, and T. Emery (2018), 'Generations and Gender Survey study profile', Longitudinal and Life Course Studies, 9 (4), 456-65. doi:10.14301/1lcs.v9i4.500.

Gauthier, J.-A., E.D. Widmer, P. Bucher, and C. Notredame (2010), 'Multichannel sequence analysis applied to social science data', Sociological Methodology, 40 (1), 1-38. doi:10.1111/j.1467-9531 .2010.01227.x.

Giele, J.Z. and G.H. Elder (1998), 'Life course research: Development of a field', in J.Z. Giele and G.H. Elder (eds), Methods of Life Course Research: Qualitative and Quantitative Approaches, Thousand Oaks, CA: Sage, pp. 5-27.

Glick, P. (1947), 'The family cycle', American Sociological Review, 12, 164-74. doi:10.2307/346771. 
Heinz, W.R. (2003), 'From work trajectories to negotiated careers: The contingent work life course', in J.T. Mortimer and M.J. Shanahan (eds), Handbook of the Life Course, New York: Kluwer Academic Plenum Publishers, pp. 185-204.

Henz, U. and E. Thomson (2005), 'Union stability and stepfamily fertility in Austria, Finland, France and West Germany', European Journal of Population, 21 (1), 3-29.

Huinink, J., J. Brüderl, B. Nauck, S. Walper, L. Castiglioni, and M. Feldhaus (2011), 'Panel analysis of intimate relationships and family dynamics (pairfam): Framework and design of pairfam', Zeitschrift für Familienforschung, 23 (1), 77-101. https://nbn-resolving.org/urn:nbn:de:0168-ssoar-376463.

Inglehart, R. (1971), 'The silent revolution in Europe: Intergenerational change in post-industrial societies', American Political Science Review, 65 (4), 991-1017. doi:10.2307/1953494.

Ivanova, K., M. Kalmijn, and W. Uunk (2013), 'The effect of children on men's and women's chances of re-partnering in a European context', European Journal of Population, 49 (4), 417-44. doi:10.1007/ s10680-013-9294-5.

Jalovaara, M. and A.E. Fasang (2015), 'Are there gender differences in family trajectories by education in Finland?', Demographic Research, 33, 1241-56. doi:10.4054/DemRes.2015.33.44.

Jalovaara, M. and H. Kulu (2018), 'Separation risk over union duration: An immediate itch?', Europan Sociological Review, 34 (5), 486-500. doi:10.1093/esr/jcy017.

Jónsson, A. (2018), 'Family policies, childbearing, and economic crisis: The case of Iceland', Demographic Research, 39, 561-92. doi:10.4054/DemRes.2018.39.19.

Kohli, M. (1985), 'Die Institutionalisierung der Lebenslaufs. Historische Befunde und theoretische Argumente', Kölner Zeitschrift für Soziologie und Sozialpsychologie, 37, 1-29. doi:10.1007/978-3 $-322-80354-2 \_12$.

Kohli, M. (1986), 'The world we forgot: A historical review of the life course', in V. Marshall (ed.), Later Life: The Social Psychology of Aging, Berkeley Hills, CA: Sage, pp. 271-303.

Kohli, M. (2007), 'The institutionalization of the life course: Looking back to look ahead', Research in Human Development, 4 (3-4), 253-71. doi:10.1080/15427600701663122.

Kohli, M. and J.W. Meyer (1986), 'Social structure and social construction of life stages', Human Development, 29, 145-9. doi:10.1159/000273038.

Konietzka, D. (2010), Zeiten des Übergangs. Über den Wandel der Lebensphase zwischen Jugend und Erwachsenenalter, Wiesbaden: Springer.

Kreyenfeld, M. (2002), 'Time-squeeze, partner effect or self-selection? An investigation into the positive effect of women's education on second birth risks in West Germany', Demographic Research, 7, 16-48. doi:10.4054/DemRes.2002.7.2.

Kreyenfeld, M. (2003), 'Crisis or adaptation reconsidered: A comparison of East and West German fertility patterns in the first six years after the "Wende"', European Journal of Population, 19 (3), 303-29. doi:10.1023/A:1024992712815.

Lansing, J. B. and L. Kish (1957), 'Family life cycle as an independent variable', American Sociological Review, 22 (5), 512-19. doi:10.2307/2089474.

Lesthaeghe, R. (1995), 'The second demographic transition in western countries: An interpretation', in K. Oppenheim Mason and A.-M. Jensen (eds), Gender and Family Change in Industrialized Countries, Oxford: Clarendon Press, pp. 17-62.

Levy, R., P. Ghisletta, J.-M. Goff, D. Spini, and E. Widmer (2005), Towards an Interdisciplinary Perspective on the Life Course, Amsterdam: Elsevier.

Liefbroer, A. and E. Dourleijn (2006), 'Unmarried cohabitation and union stability: Testing the role of diffusion using data from 16 European countries', Demography, 43 (43), 203-21. doi:10.1353/dem .2006 .0018 .

Liefbroer, A. and H.C. Elzinga (2012), 'Intergenerational transmission of behavioural patterns: How similar are parents' and children's demographic trajectories?', Advances in Life Course Research, 17 (1), 1-10. doi:10.1016/j.alcr.2012.01.002.

Linton, R. (1942), 'Age and sex categories', American Sociologcal Review, 7 (5), 589-603. doi:10.2307/ 2085685.

Lois D. and O. Arránz Becker (2014), 'Is fertility contagious? Using panel data to disentangle mechanisms of social network influences on fertility decisions', Advances in Life Course Research, 21, 123-34. doi:10.1016/j.alcr.2013.10.001. 
Mannheim, K. (1952), 'The sociological problem of generations', in P. Kecskemeti (ed.), Essays on the Sociology of Knowledge, New York: Oxford University Press, pp. 163-95.

Marini, M.M. (1984), 'Age and sequencing norms in the transition to adulthood', Social Forces, 63 (1), 229-44. doi: $10.2307 / 2578867$.

Matysiak, A. and D. Vignoli (2008), Fertility and women's employment: A meta-analysis', European Journal of Population, 24 (4), 363-84. www.jstor.org/stable/40271645.

Mayer, K.U.(1990), 'Lebensverläufe und sozialer Wandel. Anmerkungen zu einemForschungsprogramm', in K.U. Mayer (ed.), Lebensverläufe und sozialer Wandel, Opladen: Westdeutscher Verlag, pp. 7-21.

Mayer, K.U. (2004), 'Whose lives? How history, societies, and institutions define and shape life courses', Research in Human Development, 3, 161-87. doi:10.1207/s15427617rhd0103 3.

Mayer, K.U. (2009), 'New directions in life course research', Annual Review of Sociology, 35, 413-33. doi:10.1146/annurev.soc.34.040507.134619.

Mayer, K.U. and U. Schoepflin (1989), 'The state and the life course', Annual Reviews of Sociology, 15, 187-209. www.jstor.org/stable/2083224.

Mayer, K.U. and N.B. Tuma (1990), 'Life course research and event history analysis: An overview', in K.U. Mayer and N.B. Tuma (eds), Event History Analysis in Life Course Research, Madison, WI: University of Wisconsin Press, pp. 3-20.

Morosow, K. and H. Trappe (2018), 'Intergenerational transmission of fertility timing in Germany', Demographic Research, 38, 1389-422. doi:10.4054/DemRes.2018.38.46.

Mortimer, J.T. (2008), 'From social structure and personality to life course sociology: Glen Elder's legacy at the University of Minnesota', Research in Human Development, 5 (4), 216-30. doi:10.1080/ 15427600802493940.

Neyer, G. and G. Andersson (2008), 'Consequences of family policies on childbearing behavior: Effects or artifacts?', Population and Development Review, 34 (4), 699-724. doi:10.1111/j.1728-4457.2008 .00246.x.

Pavalko, E.K. and G.H. Elder (1990), 'World War II and divorce: A life-course perspective', American Journal of Sociology, 95 (5), 1213-34. www.jstor.org/stable/2780515.

Poortman, A.-R. (2018), 'Postdivorce parent-child contact and child well-being: The importance of predivorce parental involvement', Journal of Marriage and Family, 80 (3), 671-83. doi:10.1111/jomf .12474 .

Riley, M.W. (1987), 'On the significance of age in sociology', American Sociological Review, 52 (1), 1-14. doi:10.2307/2095388.

Rindfuss, R.R., C.G. Swicegood, and R.A. Rosenfeld (1987), 'Disorder in the life course: How common and does it matter?', American Sociological Review, 52 (6), 785-801. doi:10.2307/2095835.

Ryder, N.B. (1965), 'The cohort as a concept in the study of social change', American Sociological Review, 30 (6), 843-61. doi:10.2307/2090964.

Settersten, R.A. (2003), 'Age structuring and the rhythm of the life course', in J.T. Mortimer and M.J. Shanahan (eds), Handbook of the Life Course, New York: Kluwer Academic Plenum Publishers, pp. 81-98.

Settersten, R.A. and G.O. Hägestad (1996), 'What's the latest? Cultural age deadlines for family transitions', The Gerontologist, 36 (2), 178-88. doi:10.1093/geront/36.2.178.

Settersten, R.A. and K.U. Mayer (1997), 'The measurement of age, age structuring, and the life course', Annual Review of Sociology, 23, 233-61. doi:10.1146/annurev.soc.23.1.233.

Staudinger, U.M. (2015), 'Images of aging: Outside and inside perspectives', Annual Review of Gerontology and Geriatrics, 35 (1), 187-209. doi:10.1891/0198-8794.35.187.

Van Winkle, Z. (2018), 'Family trajectories across time and space: Increasing complexity in family life courses in Europe?', Demography, 55, 135-64. doi:10.1007/s13524-017-0628-5.

Wingens, M. (2020), Soziologische Lebenslaufforschung, Wiesbaden: Springer.

Zimmermann, O. (2020), 'Destandardization in later age spans in Western Germany: Evidence from sequence analysis of family life courses', Advances in Life Course Research, 43, pp. 1-15. doi:10 .1016/j.alcr.2019.04.017.

Zimmermann, O. and D. Konietzka (2018), 'Social disparities in destandardization: Changing family life course patterns in seven European countries', European Sociological Review, 34 (1), 64-78. doi:10 .1093/esr/jcx083. 